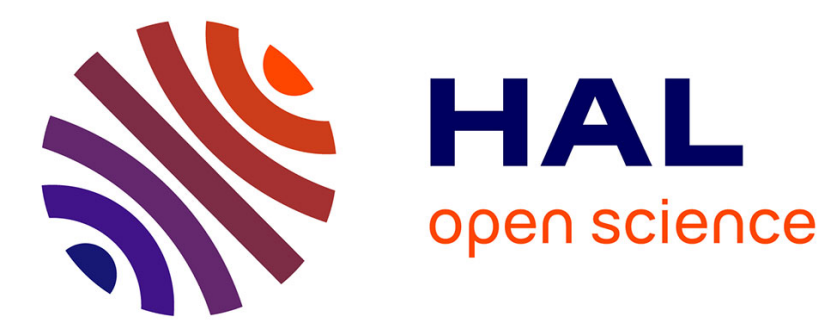

\title{
Biocontrol agents and natural compounds against mycotoxinogenic fungi
}

\author{
Selma Snini, Florence Mathieu
}

\section{To cite this version:}

Selma Snini, Florence Mathieu. Biocontrol agents and natural compounds against mycotoxinogenic fungi. Toxins, 2020, 12 (6), pp.353. 10.3390/toxins12060353 . hal-02878809

\section{HAL Id: hal-02878809 \\ https://hal.science/hal-02878809}

Submitted on 23 Jun 2020

HAL is a multi-disciplinary open access archive for the deposit and dissemination of scientific research documents, whether they are published or not. The documents may come from teaching and research institutions in France or abroad, or from public or private research centers.
L'archive ouverte pluridisciplinaire HAL, est destinée au dépôt et à la diffusion de documents scientifiques de niveau recherche, publiés ou non, émanant des établissements d'enseignement et de recherche français ou étrangers, des laboratoires publics ou privés. 


\section{OATAO \\ Open Archive Toulouse Archive Ouverte}

\section{Open Archive Toulouse Archive Ouverte}

OATAO is an open access repository that collects the work of Toulouse researchers and makes it freely available over the web where possible

This is a publisher's version published in: https://oatao.univ-toulouse.fr/26103

\section{Official URL:}

https://doi.org/10.3390/toxins12060353

\section{To cite this version:}

Snini, Selma compounds against Mycotoxinogenic Fungi. (2020) Toxins, 12 (6). 353. ISSN 2072-6651.

Any correspondence concerning this service should be sent to the repository administrator: tech-oatao@listes-diff.inp-toulouse.fr 


\title{
Biocontrol Agents and Natural Compounds against Mycotoxinogenic Fungi
}

\author{
Selma Pascale Snini (1) and Florence Mathieu* \\ Laboratoire de Génie Chimique, Université de Toulouse, CNRS, 31326 Toulouse, France; \\ selma.snini@toulouse-inp.fr \\ * Correspondence: florence.mathieu@toulouse-inp.fr
}

Received: 4 May 2020; Accepted: 26 May 2020; Published: 28 May 2020

Mycotoxins are toxic fungal secondary metabolites that contaminate food and feed. Mycotoxin contamination occurs as soon as environmental conditions are favorable for fungal growth and mycotoxin production, in the fields, during storage of raw materials and during industrial processes. To reduce mycotoxin contamination, several methods could then be adopted at these different stages. These methods can either reduce fungal growth or directly reduce the mycotoxin amount. For several years, the use of phytopharmaceutical products was favored to reduce fungal infection and thus mycotoxin contamination. However, they present numerous disadvantages such as detrimental effects in mammals, environmental contamination and subsequent strong impact on microbial biodiversity [1]. Moreover, the recurring application of fungicides could lead to the development of fungal resistance which would compromise disease control [2]. For several years, to reduce the use of such chemical products, alternative strategies based on biocontrol agents (BCAs) or natural products have been investigated.

Among mycotoxins, aflatoxin B1 (AFB1), mainly produced by Aspergillus flavus, is the most potent naturally occurring carcinogen and causes human hepatocarcinoma. Currently, to reduce AFB1 contamination in the fields, the use of atoxigenic strains is the most commonly used biological control method. In their study, Savić et al. isolated a native atoxigenic A. flavus strain from maize grown in Serbia and used it to produce a biocontrol product. The efficiency of the biocontrol product was evaluated in maize Serbian fields over two years. The results demonstrated that the biocontrol treatment had a highly significant effect in reducing total aflatoxin contamination by $73 \%$ [3]. While A. flavus is a saprophytic fungus, cereal crops can also be infected by phytopathogens which produce mycotoxins. Among them, the genus Fusarium is the most prevalent and represents a significant risk. To date, in Europe, for Fusarium spp, only two BCAs are available. To fill this lack of BCAs against Fusarium spp, Pellan et al. selected three commercial BCAs with contrasting uses and microorganism types (Trichoderma asperellum, Streptomyces griseoviridis, Pythium oligandrum) and studied their effect on Fusarium graminearum and Fusarium verticillioides growth and mycotoxin production. They observed variable levels of mycotoxin production and growth reduction depending on the BCA or the culture conditions, suggesting contrasting biocontrol mechanisms [4].

In addition to BCAs, microbial culture supernatants or extracts can also be used to reduce mycotoxin contamination. Indeed, microorganisms can produce several kinds of metabolites with biological activities. In this context, Zeidan et al. explored the antifungal potential of a Qatari strain of Burkholderia cepacia (QBC03). Their results demonstrate that this strain exhibits antifungal activity against a wide range of fungi belonging to the Aspergillus, Fusarium and Penicillium genera. Moreover, the addition of the B. cepacia culture supernatant $(2.5 \%$ to $15.5 \%)$ in the culture medium drastically reduces the fungal growth of Penicillium verrucosum, Aspergillus carbonarius and Fusarium culmorum. Further studies will be conducted to decipher the precise mechanism of action of the antifungal compounds secreted by this B. cepacia strain [5]. In the same way, Hanif et al. demonstrated that fengycin extracted from Bacillus amyloliquefaciens FZB42 inhibits F. graminearum growth and mycotoxin 
production [6]. Similar to microbial metabolites, natural compounds can also affect fungal growth and mycotoxin production. They are extracted from plants and they can be used as aqueous extracts, organic extracts or essential oils. Wang et al. demonstrated that citral essential oil completely suppressed the mycelial growth of Alternaria alternata at the concentration of $222.5 \mu \mathrm{g} / \mathrm{mL}$, which is the minimal inhibitory concentration (MIC). Moreover, the $1 / 2$ MIC of this essential oil inhibits more than $97 \%$ of the mycotoxin amount. A comparative transcriptomic analysis of $A$. alternata treated or untreated revealed that citral affects transcription of genes involved in alternariol biosynthesis [7]. In the same way, Degola et al. investigated the biological activity of Citrullus colocynthis stem, leaf and root extracts on A. flavus. Among the tested tissues, leaf and root extracts showed the highest levels of AFB1 reduction (up to $80 \%$ reduction) [8].

BCAs can also be applied during industrial processes to limit fungal growth and mycotoxin contamination. As an example, in the brewing process, Geotricum candidum, a filamentous yeast is used to reduce Fusarium spp. growth and the T-2 toxin concentration. Kawtharani et al. demonstrated that G. candidum produces phenyllactic acid at the early stages of growth, which is responsible for the reduction of the T-2 toxin concentration through the reduction in Fusarium spp. growth [9].

The last scientific article included in this Special Issue is on the fringe of the other articles and deals with the use of fullerol nanoparticles (FNP) to modulate the secondary metabolite profile of the most relevant foodborne mycotoxigenic fungi belonging to the genera Aspergillus, Fusarium, Alternaria and Penicillium. This is a preliminary study to present the proof of concept for the use of FNP against mycotoxin contamination. Thus, Kovac et al. demonstrated that exposure to FNP leads to the reduction in concentrations of 35 secondary metabolites depending on the concentration of the applied FNP and the fungal genus [10].

Acknowledgments: We express our gratitude to all contributing authors and reviewers.

Conflicts of Interest: The authors declare no conflict of interest.

\section{References}

1. Zubrod, J.; Bundschuh, M.; Arts, G.; Brühl, C.; Imfeld, G.; Knäbel, A.; Payraudeau, S.; Rasmussen, J.; Rohr, J.; Scharmüller, A.; et al. Fungicides—an Overlooked Pesticide Class? Environ. Sci. Technol. 2019, 53, 3347-3365. [CrossRef] [PubMed]

2. Lucas, J.A.; Hawkins, N.J.; Fraaije, B.A. The Evolution of Fungicide Resistance. In Advances in Applied Microbiology; Elsevier Ltd: Amsterdam, The Netherlands, 2015; Volume 90, pp. $29-92$.

3. Savic, Z.; Jaji, I.; Stankov, A.; Vukoti, J. Biological Control of Aflatoxin in Maize Grown in Serbia. Toxins 2020, 12, 162. [CrossRef] [PubMed]

4. Pellan, L.; Durand, N.; Martinez, V.; Fontana, A.; Schorr-Galindo, S.; Strub, C. Commercial biocontrol agents reveal contrasting comportments against two mycotoxigenic fungi in cereals: Fusarium graminearum and Fusarium verticillioides. Toxins 2020, 12, 152. [CrossRef] [PubMed]

5. Zeidan, R.; Ul-Hassan, Z.; Al-Thani, R.; Migheli, Q.; Jaoua, S. In-vitro Application of a Qatari Burkholderia cepacia strain (QBC03) in the Biocontrol of Mycotoxigenic Fungi and in the Reduction of Ochratoxin A biosynthesis by Aspergillus carbonarius. Toxins 2019, 11, 700. [CrossRef] [PubMed]

6. Hanif, A.; Zhang, F.; Li, P.; Li, C.; Xu, Y.; Zubair, M.; Zhang, M.; Jia, D.; Zhao, X.; Liang, J.; et al. Fengycin produced by Bacillus amyloliquefaciens FZB42 inhibits Fusarium graminearum growth and mycotoxins biosynthesis. Toxins 2019, 11, 295. [CrossRef] [PubMed]

7. Wang, L.; Jiang, N.; Wang, D.; Wang, M. Effects of essential oil citral on the growth, mycotoxin biosynthesis and transcriptomic profile of alternaria alternata. Toxins 2019, 11, 553. [CrossRef] [PubMed]

8. Degola, F.; Marzouk, B.; Gori, A.; Brunetti, C.; Dramis, L.; Gelati, S.; Buschini, A.; Restivo, F.M. Aspergillus flavus as a model system to test the biological activity of botanicals: An example on citrullus colocynthis $\mathrm{L}$. schrad. organic extracts. Toxins 2019, 11, 286. [CrossRef] [PubMed] 
9. Kawtharani, H.; Snini, S.P.; Heang, S.; Bouajila, J.; Taillandier, P.; Mathieu, F.; Beaufort, S. Phenyllactic acid produced by Geotrichum candidum reduces Fusarium sporotrichioides and F. langsethiae growth and T-2 toxin concentration. Toxins 2020, 12, 209. [CrossRef] [PubMed]

10. Kovac, T.; Šarkanj, B.; Borišev, I.; Djordjevic, A.; Jovic, D.; Loncaric, A.; Babic, J.; Jozinovi, A.; Krska, T.; Gangl, J.; et al. Fullerol $\mathrm{C}_{60}(\mathrm{OH})_{24}$ Nanoparticles Affect Secondary Metabolite Profile of Important Foodborne Mycotoxigenic Fungi In Vitro. Toxins 2020, 12, 213. [CrossRef] [PubMed] 